\title{
NONLINEAR ANALYSIS OF WITH AND WITHOUT STIFFENERS OF HOLLOW AND CONCRETE FILLED STEEL TUBE COLUMN BY USING ABAQUS 6.10-1
}

\author{
Athiq Ulla Khanr ${ }^{1}$, N.S.Kumar ${ }^{2}$ \\ ${ }^{1}$ Master of Technology(Structural Engineering)Student, Civil Department, Ghousia College of Engineering, \\ Ramanagara-562159, Karnataka, India \\ ${ }^{2}$ Professor \& Director $(R \& D)$ Civil Department, Ghousia College of Engineering, Ramanagara-562159, Karnataka, \\ India
}

\begin{abstract}
The concrete filled steel tube(CFST) column has got many advantages compared with the reinforced concrete member. Concrete filled steel tube are frequently used for piers, deep foundation, caissons and columns etc because of their high compressive strength and stiffness. Analytical Study of Hollow Steel Tube With concrete filled of different grades and without and with steel stiffeners (one stiffener and two stiffener) under monotonic loading is presented in this Paper. The nonlinear behavior of the columns is observed by using finite element software ABAQUS 6.10-1.the results from non linear finite element analyses is obtained and is verified with experimental tests, Eurocode Part-4 and ACI-318(2005).It was found that the non linear finite element simulations are in a good agreement with the codes of practice and experimental results. this study has carried out to examine the influence of several parameters such as thickness of tube( $3 \mathrm{~mm}$ and $4 \mathrm{~mm}$ ) and stiffener configurations(i,e At 1/3 times of height and 1/2 times of height), frequency, time period and also to find Ultimate load carrying capacity of hollow and composite column on the compressive response under axial load. The hollow and composite columns are extensively developed by considering different configuration of steel stiffeners. The main variables are: (1) number of stiffeners (2) arrangement stiffeners (3) stiffener spacing (4) thickness of steel tube (5) compressive strength of concrete(20MPa, 25MPa, 30MPa). Effects of above variables mention on the behavior of columns is assessed. Failure modes and deformed shape of the columns is also illustrated. From this study it is concluded that, the developed finite element model gives closer perfection and depicts the non linear behavior well with 5-10\% error. Also the non linear behavior is examine when only steel tube is loaded, only concrete is loaded and when both is loaded and the combination of loading on both steel tube and infill concrete gave higher load carrying capacity. The analytical results are well validated with previous researchers too.
\end{abstract}

Keywords: Hollow, Composite, Capacity, Monotonic loading, Nonlinear analysis, Abaqus, fundamental frequency, time period, confinement

\section{INTRODUCTION}

In modern days, building design emphasizes on enhancing flexibility of the floor space by reducing the cross section of column size. Concrete filled steel tube are used for both unbraced and braced building structures. A CFST column consist of steel tube and concrete core inside it. The steel tube act as a permanent form work hence labour cost, time consumption is reduced. And it has got regular shapes such as rectangle, square and circular.

The steel shell acts as longitudinal and transverse reinforcement. The steel shell also provides confining pressure to the concrete, which puts the concrete under a triaxial state of stress. On the other hand, the steel tube is stiffened by the concrete core. This can prevent the inward buckling of the steel tube, and increase the stability and strength of the column.

The attraction for composite column is that the steel skeleton can be erect first, and this can support the dead loads and construction loads. Subsequent concreting increases the capacity greatly, and the composite columns, which develop when the concrete hardens, are suitable for resisting additional live loading as well as dead loads.

These composite columns can be also used for the resisting outside pressure, such as ocean waves, ice; in seismic regions because of excellent earthquake-resistant properties such as high strength, high ductility, and large energy absorption capacity.

The aim of this investigation is to employ the nonlinear finite element program ABAQUS 6.10-1[2] to perform numerical simulations of CFT columns subjected to axial compressive loads. To achieve this goal, proper material constitutive models for steel stiffener, steel tube, and concrete are proposed. Then the proposed material constitutive models are verified against experimental data and codes of practice. Finally, the influence of the concrete confining pressure, fundamental frequency and the geometric properties of the columns on the uniaxial behavior of CFT columns are studied and discussed. 


\section{FINITE ELEMENT MODELLING}

Hollow steel tube column and Concrete filled steel tube column with and without stiffener are accurately model in finite element software ABAQUS and verified with experimental results and codes of practice. The cross section of columns with steel thickness $3 \mathrm{~mm}$ and $4 \mathrm{~mm}$ and length or height of $300 \mathrm{~mm}$ are shown in figure-1.

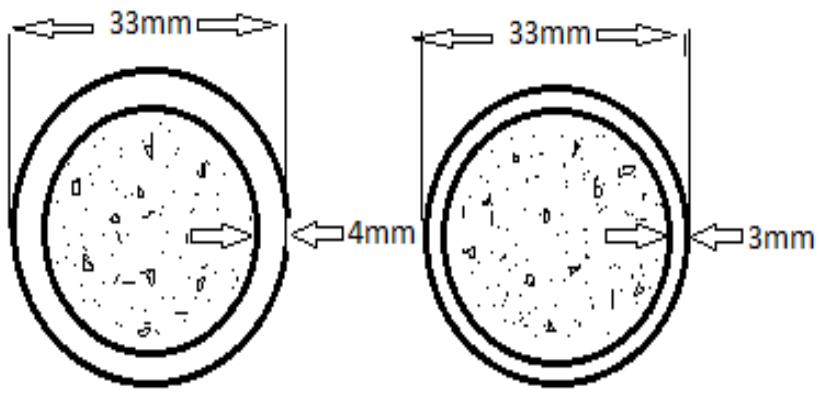

Figure-1: Cross section of Hollow and CFST columns ( $\mathrm{L}=300 \mathrm{~mm})$

\subsection{Material Properties and Constitutive Models}

Steel, concrete and contact between them are the main materials used in the numerical analysis of the columns which their properties and constitutive models are presented below.

\subsubsection{Material Model of Concrete}

In order to understand concrete behavior in the finite element model, a nonlinear stress-strain diagram for confined concrete should be establish. The equivalent stressstrain curve for confined and unconfined concrete under compressive loading as shown in figure 3 . Which is used in proposed FE model. This approach is adopted by Ellobody et al [4]

The properties of material shown in figure 2 are used to define the nonlinear behavior of concrete under confinement. Which is defined as follows

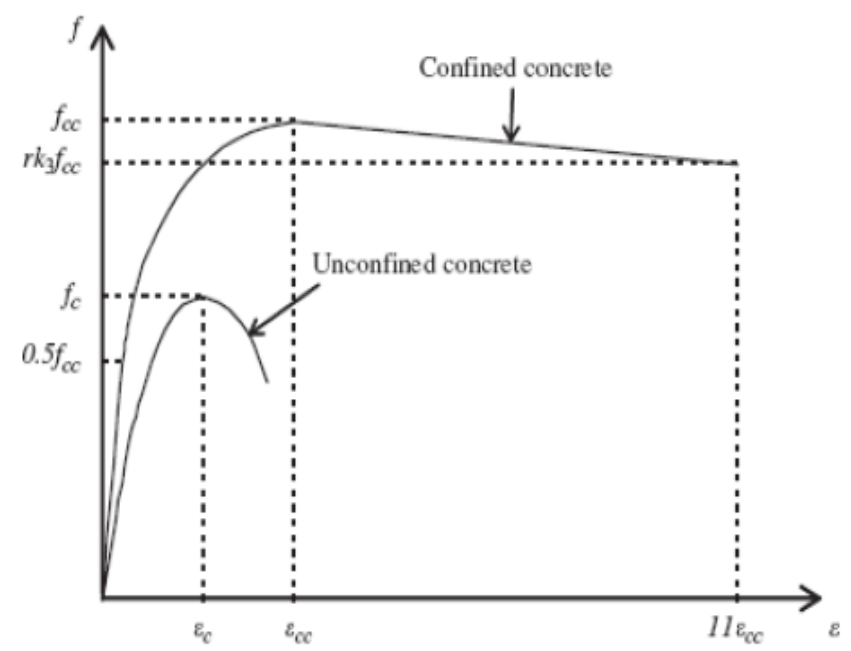

Fig .2 Equivalent stress-strain curves for confined and unconfined concrete

$$
\begin{gathered}
f_{c c}=f_{c}+k_{1} f_{1} \\
\varepsilon_{c c}=\varepsilon_{c}\left(1+k_{2} \frac{f_{1}}{f_{c}}\right)
\end{gathered}
$$

Proposed by Mander et al [7]

Where $f_{c c}=$ Confined concrete compressive strength . $f_{c}=$ Unconfined concrete cylinder compressive strength $=0.8 f_{c u}$

$f_{c u}=$ Unconfined concrete cube compressive strength $=f_{c k}$

$f_{l}=$ Lateral confining pressure from steel tube $=\frac{2 \sigma_{\theta} t}{D}$

$\sigma_{\theta}=0.1 f_{y}$

$f_{y}=$ Yield strength of steel

$\mathrm{t}=$ thickness of steel tube

$\mathrm{D}=$ outer dia steel tube

$\varepsilon_{\mathrm{cc}}=$ confined concrete strain

$\varepsilon_{\mathrm{c}}=$ Unconfined concrete strain $=0.002-0.003$

$\varepsilon_{\mathrm{c}}=0.003$, as recommended by the ACI specification [1]

the factor $\mathrm{k}_{1}$ and $\mathrm{k}_{2}$ are taken as 4.1 and 20.5 respectively, given by Richart et al.[6]

The stress-strain curve is divided into three parts namely; Elastic part(Linear), Elasto-Plastic part and Perfectly plastic(non linear).

The first part is linear upto $0.5 f_{c c}$ at which stress is proportional to strain given by $\mathrm{Hu}$ et al.[10] the slope of the linear part gives elastic young's modulus of confined concrete $\mathrm{E}_{\mathrm{cc}}$. According to ACI code [1] the value of $\mathrm{E}_{\mathrm{cc}}$ is given by

$$
E_{c c}=4700 \sqrt{f_{c c}} M P a
$$

The poisson's ratio of Unconfined concrete is assumed to be $\mu_{\mathrm{cc}}=0.2$.

The second part is elasto-plastic which is nonlinear whose origin starts from the end of first part that is $0.5 f_{c c}$ and ends at confined concrete strength $f_{c c}$ as shown in figure 2 . This nonlinear part can be determined from the following equation, proposed by Saenz [5]

$$
f=\frac{E_{c c} \varepsilon}{1+\left(R+R_{E}-2\right)\left(\frac{\varepsilon}{\varepsilon_{c c}}\right)-(2 R-1)\left(\frac{\varepsilon}{\varepsilon_{c c}}\right)^{2}+R\left(\frac{\varepsilon}{\varepsilon_{c c}}\right)^{a}}
$$

In the above equation $\mathrm{R}$ and $\mathrm{R}_{\mathrm{E}}$ can be calculated as

$$
\begin{gathered}
R_{E}=\frac{E_{c c} \varepsilon_{c c}}{f_{c c}} \\
R=\frac{R_{E}\left(R_{\sigma}-1\right)}{\left(R_{\varepsilon}-1\right)^{2}}-\frac{1}{R_{\varepsilon}}
\end{gathered}
$$

In which $\mathrm{R}_{\sigma}$ and $\mathrm{R}_{\varepsilon}$ are equal to four as recommended by $\mathrm{Hu}$ and Schnobrich [9] 
The third part is a perfectly plastic, which starts from confined concrete strength $f_{c c}$ and ends at $\mathrm{rk}_{3} f_{c c}$ with corresponding strain value $11 \varepsilon_{\mathrm{cc}}$ as shown in figure 2 , proposed by $\mathrm{Hu}$ et al. [10]

$$
k_{a}= \begin{cases}1 & 21.7 \leq \frac{D}{t} \leq 40 \\ 0.00003391\left(\frac{D}{t}\right)^{2}-0.010085\left(\frac{D}{t}\right)+1.3 & 40 \leq \frac{D}{t} \leq 150\end{cases}
$$

The approximate value of $r$ is calculated from empirical equation recommended by Ellobody et al.[4]

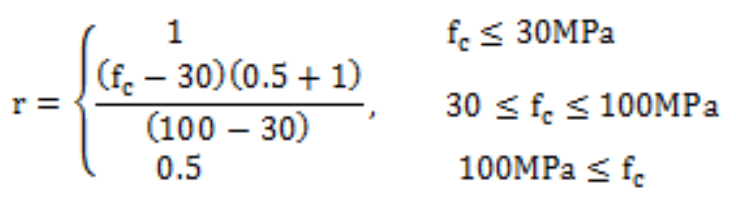

There are several nonlinear materials definition are provided in ABAQUS 6.10-1 for study of nonlinear behavior of concrete materials. In this paper concrete is modeled by plastic available in the ABAQUS [2] material library. In which nonlinear stress-strain values of confined concrete is introduced calculated from the above equations.

\subsubsection{Material Model of Steel}

Steel tube is modeled as elastic-perfectly plastic with von mises yield criterion. Due to steel tube is subjected to multiple stresses and therefore the stress-strain curve crosses elastic limit and reaches in plastic region. The nonlinear behavior of steel tube is obtained from uniaxial tension test and used in steel modeling. In this analysis poisson's ratio, density and young's modulus are taken as $\mu=0.3$, $\int=7860 \mathrm{~kg} / \mathrm{m}^{3}$ and $\mathrm{E}_{\mathrm{s}}=210000 \mathrm{MPa}$, respectively.

\subsubsection{Material Model of Stiffener}

The behavior of steel stiffener is simulated in finite element analysis is same as steel tube. The stiffener is discretised by using one dimensional element that is beam element $-\mathrm{B} 31$ whose element size is taken as 2.5. In this analysis Poisson's ratio, density and young's modulus are taken as $\mu=0.3$, $\int=7860 \mathrm{~kg} / \mathrm{m}^{3}$ and $\mathrm{E}_{\mathrm{s}}=210000 \mathrm{MPa}$, respectively.

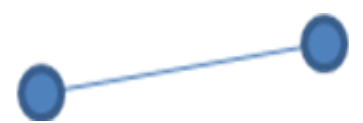

Fig-2 Beam Element type-B31

\subsubsection{Concrete-Steel Interface}

The contact between steel tube and concrete play a vital role in analysis. There are two ways to provide contact between steel tube and concrete, one is providing friction by considering suitable co efficient and another one is NODE MERGE that is merging of inner periphery nodes of steel tube with outer periphery of concrete core so that it provides good contact between steel tube and concrete core. Here NODE MERGE is applied.

\subsection{Modeling and Meshing}

The 3D hollow and concrete filled steel tube columns with and without stiffener is created in Hypermesh-11.0 software and then exported to ABAQUS. Because creating stiffener is difficult in ABAQUS. The element library of finite element software ABAQUS-6.10.1 is used to select different types of elements. This library provides 1D element(Beam element, Truss Element), 2D element (Shell element) and 3D elements (solid elements).solid elements were found to be more efficient in modeling of concrete and steel tube because it gives better capturing of stiffness and mass. The three dimensional incompatable eight noded solid element(C3D8I) is used for meshing and is illustrated in figure 3 .

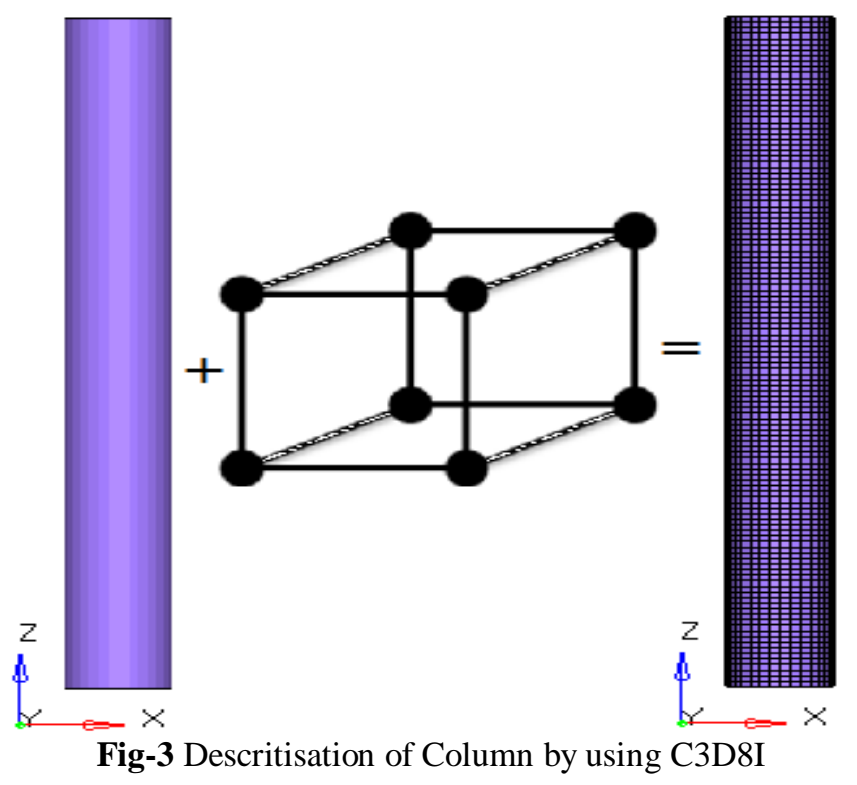

\subsection{Load Application}

A compressive load is uniformly distributed over the top surface of column nodes as shown in figure 4. The load is applied in Z-direction and is allow to move freely in Zdirection but restrained in $\mathrm{X}$ and $\mathrm{Y}$-direction.

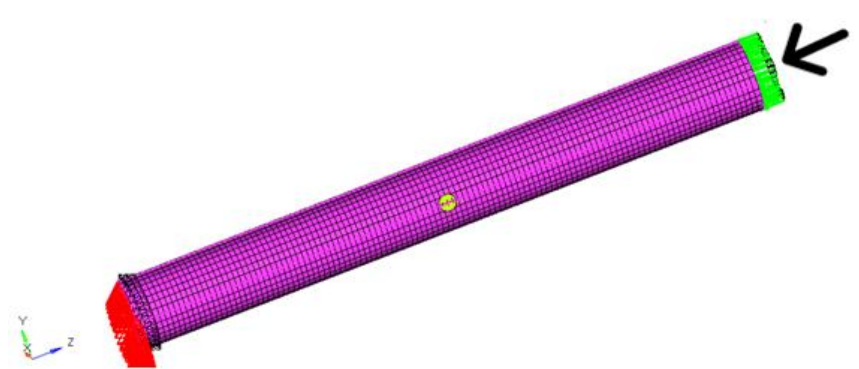

Fig-4 Load applied on each node of top surface.

\subsection{Boundary Conditions}

Bottom end of the column is fixed in all directions that is $\Delta_{\mathrm{X}}=0, \Delta_{\mathrm{y}}=0, \Delta_{\mathrm{z}}=0$. Top surface of the column is restrained in $\mathrm{X}$ and Y-direction $\left(\Delta_{\mathrm{x}}=0, \Delta_{\mathrm{y}}=0\right)$ and allowing displacement in Z-direction as shown in figure 5. 


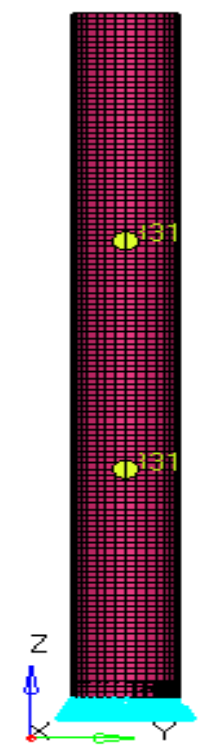

Fig-5 Fixed at Bottom

\subsection{Solution Procedure}

First static analysis is performed and then procedure is changed to linear buckling analysis, which gives Eigen values. The first Eigen value is considered as Buckling load factor or critical load for linear analysis. First Eigen value because the column will break at first load and there are less chance to go second critical load. But a material reaches to nonlinearity action so therefore nonlinear analysis is performed.

There are several nonlinear methods are available in ABAQUS. A RIKS analysis is performed to understand nonlinear behavior of stiffened and unstiffened columns. RIKS analysis is based on Arc length and number of increments which is again depends on geometry and features of model. A nonlinear stress-strain values is introduced by selecting plasticity option in ABAQUS. The first eigen value is taken and is applied as load in Riks analysis by dividing it by Number of nodes.

Now job is created and submitted to run the analysis. The output gives a nonlinear graph which is plotted against Load Prediction Factor(LPF) verses Arc length. The LPF value corresponding to ultimate point is taken from the graph and multiplied with first eigen value obtained from linear buckling analysis which gives Ultimate load carrying capacity $\left(\mathrm{P}_{\mathrm{U}}\right)$

\section{VERIFICATION OF FINITE ELEMENT}

\section{MODEL}

\subsection{Experimental Results}

In order to check the accuracy of the finite element model, the modeling results were compared with experimental tests results which is carried out by using Universal Testing Machine (UTM). The Ultimate loads obtained from finite element analysis is $\mathrm{P}_{\mathrm{FE}}$ and that for experimental tests is $\mathrm{P}_{\text {expt }}$. Table 1 shows comparision study of the Ultimate loads of Hollow and CFST columns obtained Experimentally and numerically using the finite element model. It was found that the non linear finite element simulations are in a good agreement with the experimental results.

\section{ANALYTICAL STUDY}

\subsection{Eurocode 4}

EC4[3] is the most recently completed international standard code for composite construction. It covers CFST columns with or without reinforcement. EC4 consider the confinement effect for composite column when relative slenderness $\operatorname{ratio}(\lambda)$ has value less than 0.5 . the ultimate axial force for square column is given by

$$
P_{u}=A_{c} f_{c}+A_{s} f_{s}
$$

Where; $A_{c}$ and $A_{s}$ are the Area of concrete and steel respectively, and $f_{c}$ and $f_{s}$ are the yield strength of concrete and steel respectively.

For circular columns, confinement effect has to be consider if the relative slenderness ratio $\lambda$ is less than 0.5 .

Where $\lambda$ is given by $\mathrm{N}_{\mathrm{cr}}$

$$
\begin{gathered}
\lambda=\sqrt{\frac{\mathrm{A}_{s} \mathrm{f}_{s}+085 \mathrm{~A}_{\mathrm{c}} \mathrm{f}_{\mathrm{c}}}{\mathrm{N}_{\mathrm{cr}}}} \\
N_{c r}=\frac{\left(\mathrm{E}_{\mathrm{g}} \mathrm{I}_{s}+\mathrm{E}_{\mathrm{c}} \mathrm{I}_{\mathrm{c}}\right) \mathrm{\pi}^{2}}{1^{2}} \\
\eta_{1}=4.9-18.5 \lambda+17 \lambda^{2}+1 \\
\eta_{2}=0.25(3+2 \lambda) \\
\mathrm{P}_{\mathrm{u}}=\mathrm{A}_{\mathrm{c}} \mathrm{f}_{\mathrm{c}} \eta_{2}+\mathrm{A}_{s} \mathrm{f}_{s}\left(1+\eta_{1} \frac{t \mathrm{f}_{s}}{d \mathrm{f}_{\mathrm{c}}}\right)
\end{gathered}
$$

\subsection{American Concrete Institute: Building Code}

\section{Requirements For Structural Concrete}

The American concrete institute ACI[1] use the formula to calculate squash load. This code doesn't consider the effect of confinement. The squash load for circular column is given by

$$
P_{u}=0.95 A_{c} f_{c}+A_{s} f_{s}
$$

A modification for above equation is proposed by Giakoumelis and Lam[11]. A co efficient is proposed for above ACI equation to take into account the effect of confinement on axial load capacity of CFST column and for hollow first term is zero. A revised equation is given by

$$
\mathrm{P}_{\mathrm{u}}=1.3 \mathrm{~A}_{\mathrm{c}} \mathrm{f}_{\mathrm{c}}+\mathrm{A}_{\mathrm{s}} \mathrm{f}_{\mathrm{s}}
$$


The capacities given by ACI code are too conservative where as those calculated by using revised equation are more realistic, especially for circular columns.

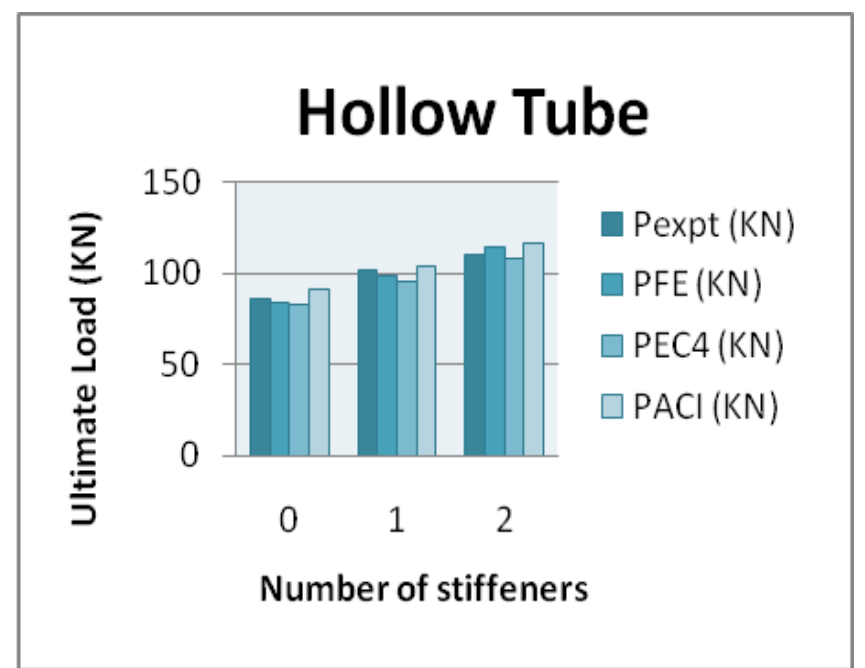

Chart-1: Hollow Tube

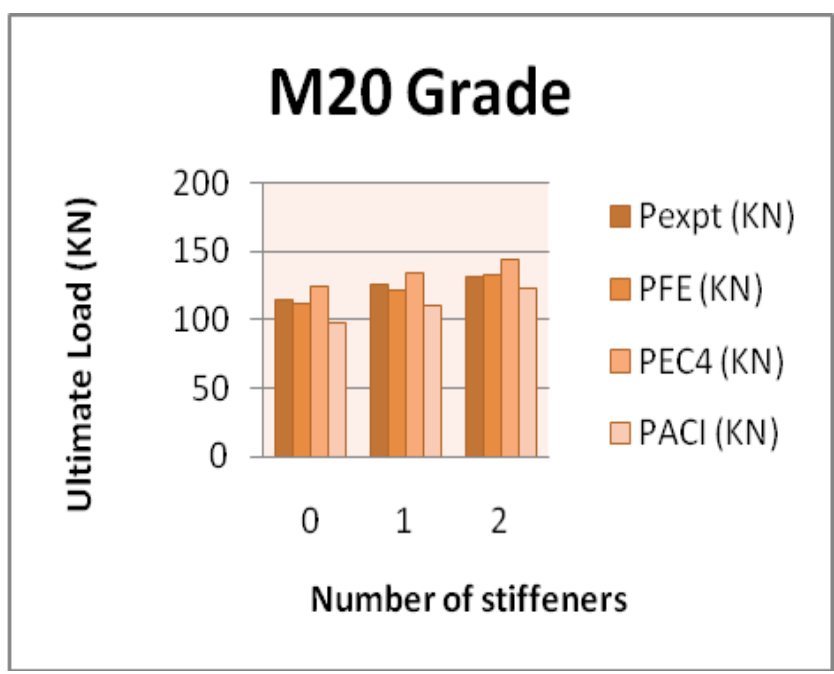

Chart-2: Grade of concrete M20

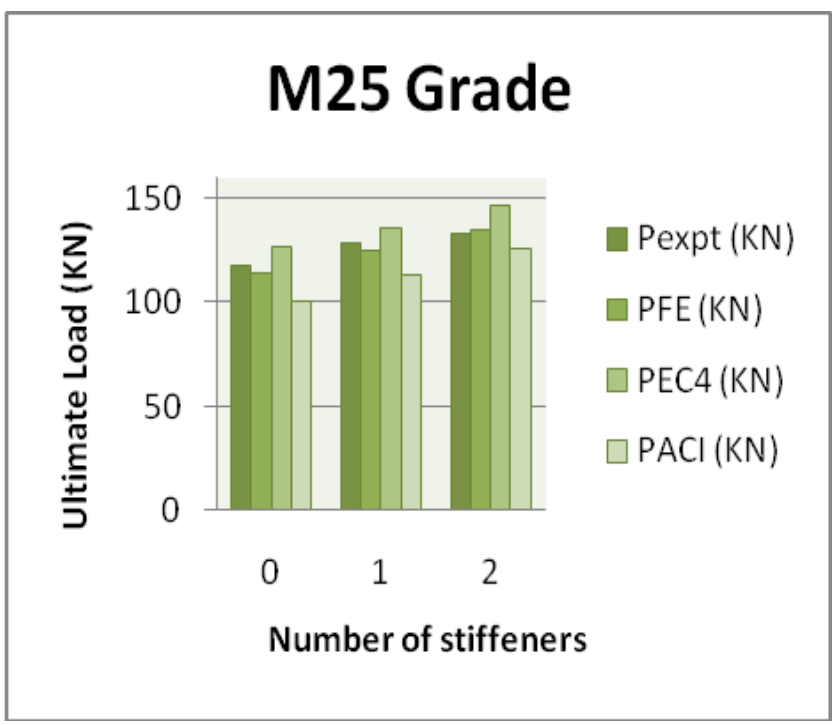

Chart-3: Grade of concrete M25

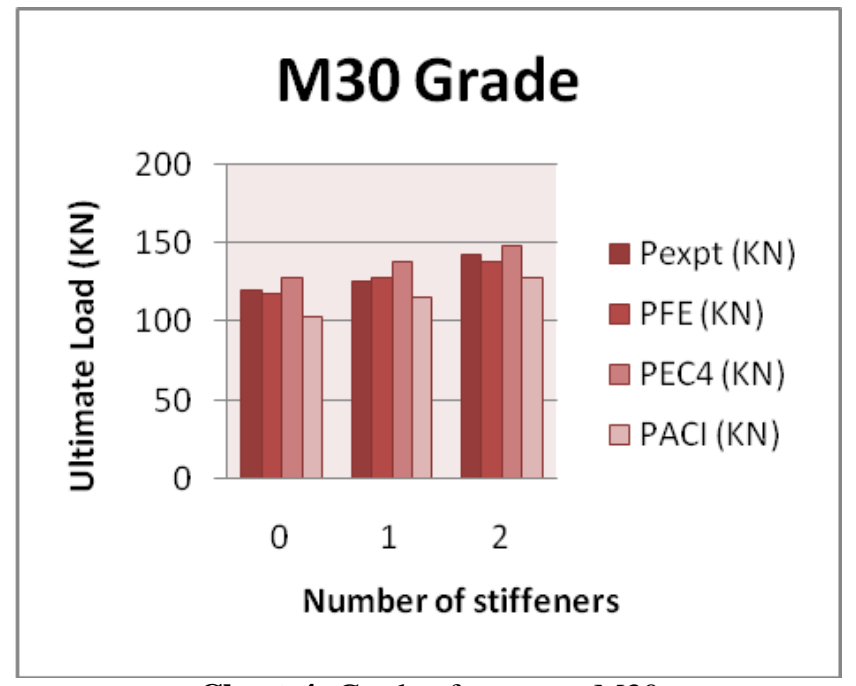

Chart-4: Grade of concrete M30

Table-1: Comparison between experiment, finite element, EC4 and ACI with $3 \mathrm{~mm}$ thickness

\begin{tabular}{|c|c|c|c|c|c|c|c|c|c|c|}
\hline Case & $\begin{array}{l}\text { Number of } \\
\text { stiffeners }\end{array}$ & $\mathrm{D}(\mathrm{mm}$ & 1) $t(\mathrm{~mm})$ & $\mathrm{D} / \mathrm{t}$ & $P_{\text {eapt }}(K Y)$ & $\mathrm{PFE}_{\mathrm{FE}}(\mathrm{K})$ & $P_{\text {eppt }} P_{F E}$ & $\mathrm{P}_{\mathrm{ECA}}(\mathrm{KN})$ & $\mathrm{P}_{\mathrm{ACI}}(\mathrm{KV})$ & $\mathrm{P}_{\mathrm{Lam}}(\mathrm{KV})$ \\
\hline \multirow{3}{*}{ Hollor } & No stiffner & 33 & 3 & 11 & 64.5 & 65.36 & 0,986 & 63.899 & 70.685 & 70.685 \\
\hline & One stiffener & 33 & 3 & 11 & 81.25 & 79 & 1.028 & 76,34 & 83.25 & 83.25 \\
\hline & Iro stiffener & 33 & 3 & 11 & 93.45 & 90.25 & 1,035 & 89.012 & 95.815 & 95.815 \\
\hline \multirow{3}{*}{1120 Grade } & No stiffner & 33 & 3 & 11 & 95,54 & 92.62 & 1,031 & 101.787 & 79,387 & 82.594 \\
\hline & one stiffener & 33 & 3 & 11 & 105.23 & 103.56 & 1.016 & 111.246 & 91,952 & 95.159 \\
\hline & ITro stiffener & 33 & 3 & 11 & 114.36 & 113.4 & 1,008 & 121.424 & 104.52 & 107.724 \\
\hline \multirow{3}{*}{.125 Grade } & No stiffner & 33 & 3 & 11 & 97,89 & 95.25 & 1.027 & 103.832 & 81.563 & 85.571 \\
\hline & One stiffener & 33 & 3 & 11 & 107.5 & 106 & 1.014 & 113,368 & 94.128 & 98.136 \\
\hline & Iro stiffener & 33 & 3 & 11 & 112 & 115.6 & 0.968 & 123.603 & 106.69 & 110.701 \\
\hline \multirow{3}{*}{ M30 Grade } & No stiffner & 33 & 3 & 11 & 98.56 & 96.9 & 1,017 & 105.827 & 83.739 & 88.548 \\
\hline & One stiffener & 33 & 3 & 11 & 109.6 & 107,95 & 1,015 & 115.519 & 96,304 & 101.113 \\
\hline & Iro stifiener & 33 & 3 & 11 & 115 & 116 & 0.991 & 125.798 & 108.86 & 113.67 \\
\hline
\end{tabular}

Table-2: Comparison between experiment, finite element, EC4 and ACI with $4 \mathrm{~mm}$ thickness

\begin{tabular}{|c|c|c|c|c|c|c|c|c|c|c|}
\hline Case & \begin{tabular}{|l} 
Number of \\
stiffeners
\end{tabular} & $\mathrm{D}(\mathrm{mm})$ & $t(\mathrm{~mm})$ & $\mathrm{D} / \mathrm{t}$ & $P_{\text {eapt }}(\mathrm{KV})$ & $P_{F E}(K V)$ & $P_{\text {exp }} / P_{F E}$ & $\mathrm{P}_{\mathrm{EC}} \mathrm{K}(\mathrm{KN})$ & $\mathrm{P}_{\mathrm{ACI}}(\mathrm{K})$ & $P_{\text {Lam }}(\mathrm{KV})$ \\
\hline \multirow{3}{*}{ Hollow } & No stiffener & 33 & 4 & 8.25 & 85.65 & 83.54 & 1.025 & 82.81 & 91.102 & 91.102 \\
\hline & One stiffener & 33 & 4 & 8.25 & 101.56 & 98.23 & 1.033 & 95.272 & 103.67 & 103.667 \\
\hline & Iro stiffener & 33 & 4 & 8.25 & 110.25 & 113.95 & 0.967 & 108.56 & 116.23 & 116.23 \\
\hline \multirow{3}{*}{$\begin{array}{l}\text { M20 } \\
\text { Grade }\end{array}$} & No stiffener & 33 & 4 & 8.25 & 115.26 & 112.56 & 1.023 & 124.752 & 98.563 & 101.312 \\
\hline & One stiffener & 33 & 4 & 8.25 & 126.5 & 122 & 1.036 & 134,324 & 111.13 & 113.877 \\
\hline & Iro stiffener & 33 & 4 & 8.25 & 132 & 133.5 & 0.988 & 144.423 & 123.69 & 126.442 \\
\hline \multirow{3}{*}{$\begin{array}{l}\text { M.25 } \\
\text { Grade }\end{array}$} & No stiffener & 33 & 4 & 8.25 & 117.32 & 114.25 & 1.026 & 126.492 & 100.43 & 103.865 \\
\hline & One stiffener & 33 & 4 & 8.25 & 128.3 & 124.6 & 1.029 & 136.116 & 112.99 & 116.43 \\
\hline & Iro stiffener & 33 & 4 & 8.25 & 133.32 & 135 & 0.987 & 146.248 & 125.56 & 128.995 \\
\hline \multirow{3}{*}{$\begin{array}{l}\text { M130 } \\
\text { Grade }\end{array}$} & No stiffener & 33 & 4 & 8.25 & 120.22 & 117.64 & 1.021 & 128.11 & 102.29 & 106.417 \\
\hline & One stiffener & 33 & 4 & 8.25 & 125.36 & 127.65 & 0.982 & 137,901 & 114.86 & 118.982 \\
\hline & Tro stiffener & 33 & 4 & 8.25 & 142.5 & 138.12 & 1.031 & 148.072 & 127.42 & 131.547 \\
\hline
\end{tabular}




\section{COMPARATIVE STUDY}

\subsection{General}

The ultimate load capacity of different hollow and CFST columns based on their thickness were found by using codes of practice (Eurcode 4 [3], ACI [1] and Giakoumelis and lam [11]). The numerical and theoretical results obtained by using above codes which denotes that with increase in thickness, enhances the capacity which is due to increase in confinement pressure.

\subsection{Effect of Hollow and Concrete Filled column}

The strength of hollow column is less than concrete filled column. The hollow column fails due to inward buckling at lower load. Where as in concrete filled steel tube, concrete try to bulge and steel tube try to buckle therefore due this opposite forces failure takes place after a long time results in increasing the capacity of column.

\subsection{Grade of Concrete}

The stiffness of CFST column is depends on strength of concrete. With increase in strength of concrete stiffness of CFST column can be increased. Since concrete is a brittle material, the concrete fails due to crushing. This brittleness is increased with increase in grade of concrete. However this concrete core is covered with steel tube which minimizes the crushing of concrete.

\subsection{Fundamental Frequencies}

The fundamental frequency, often referred to simply as the fundamental, and is defined as the lowest frequency of a periodic waveform.

From the Table-3, Table-4, Table-5 and Table- 6 it is clear that Fundamental Frequency is decreases with increasing number of stiffeners. This stiffeners act as a damping medium due which Fundamental Frequency is lowered. Also when strength of concrete increases the Fundamental Frequency decreases very fast compare with number of stiffeners, as shown in chart-5, chart-6, chart-7 and chart-8.

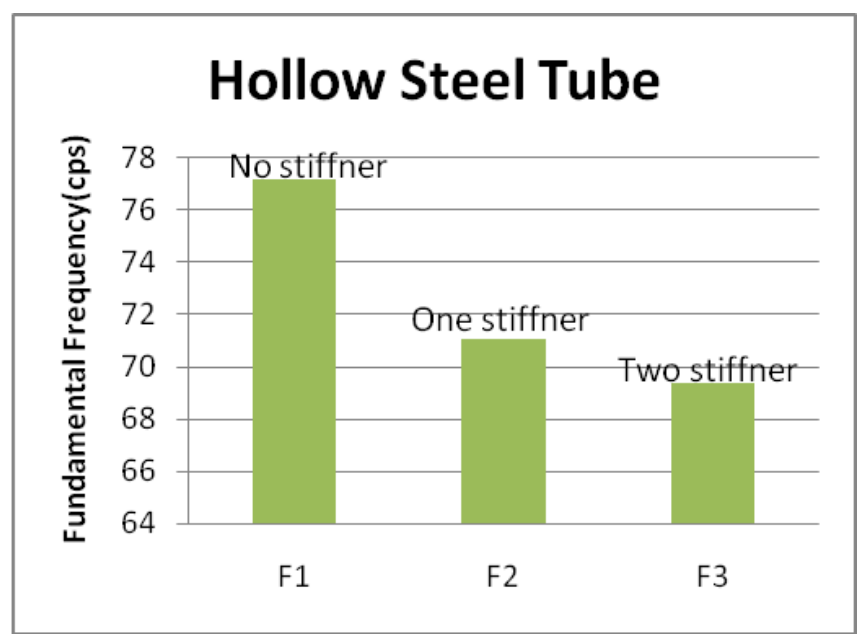

Chart-5: Fundamental Frequecy of Hollow Steel Tube
Table -3: Empty Fundamental Frequency

\begin{tabular}{|c|c|c|c|c|c|}
\hline \multirow{2}{*}{\multicolumn{2}{|c|}{ case }} & \multicolumn{4}{|c|}{ Empty } \\
\hline & & & $\omega(\mathrm{rps})$ & $\mathrm{f}(\mathrm{hz})$ & $\mathrm{T}(\mathrm{sec})$ \\
\hline \multirow{4}{*}{$\begin{array}{l}\text { Without } \\
\text { stiffner }\end{array}$} & $\lambda_{1}^{2}$ & $2.35 \mathrm{E}+05$ & 484.59 & 77.164 & 0.0129 \\
\hline & $\lambda_{2}^{2}$ & $1.83 \mathrm{E}+06$ & 1351.96 & 215.28 & 0.0046 \\
\hline & $\lambda_{3}^{2}$ & $4.09 \mathrm{E}+06$ & 2021.31 & 321.866 & 0.0031 \\
\hline & \multicolumn{3}{|c|}{ Fundamental frequency } & 77.164 & 0.0129 \\
\hline \multirow{4}{*}{$\begin{array}{l}\text { Stiffner } \\
\text { @ centre }\end{array}$} & $\lambda_{1}^{2}$ & $1.99 \mathrm{E}+05$ & 446.29 & 71.065 & 0.014 \\
\hline & $\lambda_{2}^{2}$ & $1.65 E+06$ & 1284.36 & 204.516 & 0.0048 \\
\hline & $\lambda_{3}^{2}$ & $3.69 \mathrm{E}+06$ & 1920.25 & 305.772 & 0.0032 \\
\hline & \multicolumn{3}{|c|}{ Fundamental frequency } & 71.065 & 0.014 \\
\hline \multirow{4}{*}{$\begin{array}{c}\text { Stiffner@ } \\
\text { h/3 }\end{array}$} & $\lambda_{1}^{2}$ & $1.90 \mathrm{E}+05$ & 435.54 & 69.354 & 0.0144 \\
\hline & $\lambda_{2}^{2}$ & $2.08 \mathrm{E}+05$ & 456.19 & 72.642 & 0.0137 \\
\hline & $\lambda_{3}^{2}$ & $2.21 E+05$ & 469.79 & 74.808 & 0.0133 \\
\hline & \multicolumn{3}{|c|}{ Fundamental frequency } & 69.354 & 0.0144 \\
\hline
\end{tabular}

Table -4: M20 Grade Fundamental Frequency

\begin{tabular}{|c|c|c|c|c|c|}
\hline \multirow{2}{*}{\multicolumn{2}{|c|}{ Case }} & \multicolumn{4}{|c|}{ M20 grade } \\
\hline & & & $\omega(\mathrm{rps})$ & $\mathrm{f}(\mathrm{hz})$ & $\mathrm{T}(\mathrm{sec})$ \\
\hline \multirow{4}{*}{$\begin{array}{l}\text { Without } \\
\text { stiffner }\end{array}$} & $\lambda_{1}^{2}$ & $2.21 \mathrm{E}+05$ & 469.78 & 74.8 & 0.0133 \\
\hline & $\lambda_{2}^{2}$ & $1.99 \mathrm{E}+06$ & 1411.4 & 224.749 & 0.0044 \\
\hline & $\lambda_{3}^{2}$ & $4.97 \mathrm{E}+06$ & 2229.44 & 355 & 0.0028 \\
\hline & \multicolumn{3}{|c|}{ Fundamental frequency } & 74.806 & 0.0133 \\
\hline \multirow{4}{*}{$\begin{array}{l}\text { Stiffner } \\
\text { (a)centre }\end{array}$} & $\lambda_{1}^{2}$ & $1.90 \mathrm{E}+05$ & 436.13 & 69.447 & 0.0143 \\
\hline & $\lambda_{2}^{2}$ & $1.61 \mathrm{E}+06$ & 1270.3 & 202.27 & 0.0049 \\
\hline & $\lambda_{3}^{2}$ & $4.03 E+06$ & 2006.4 & 319.49 & 0.0031 \\
\hline & \multicolumn{3}{|c|}{ Fundamental frequency } & 69.42 & 0.0143 \\
\hline \multirow{4}{*}{$\begin{array}{c}\text { Stiffner@ } \\
\mathbf{h} / \mathbf{3}\end{array}$} & $\lambda_{1}^{2}$ & $1.74 E+05$ & 417.69 & 66.512 & 0.015 \\
\hline & $\lambda_{2}^{2}$ & $1.95 \mathrm{E}+05$ & 441.14 & 70.243 & 0.0142 \\
\hline & $\lambda_{3}^{2}$ & $2.35 E+05$ & 484.59 & 77.164 & 0.0129 \\
\hline & \multicolumn{3}{|c|}{ Fundamental frequency } & 66.512 & 0.015 \\
\hline
\end{tabular}

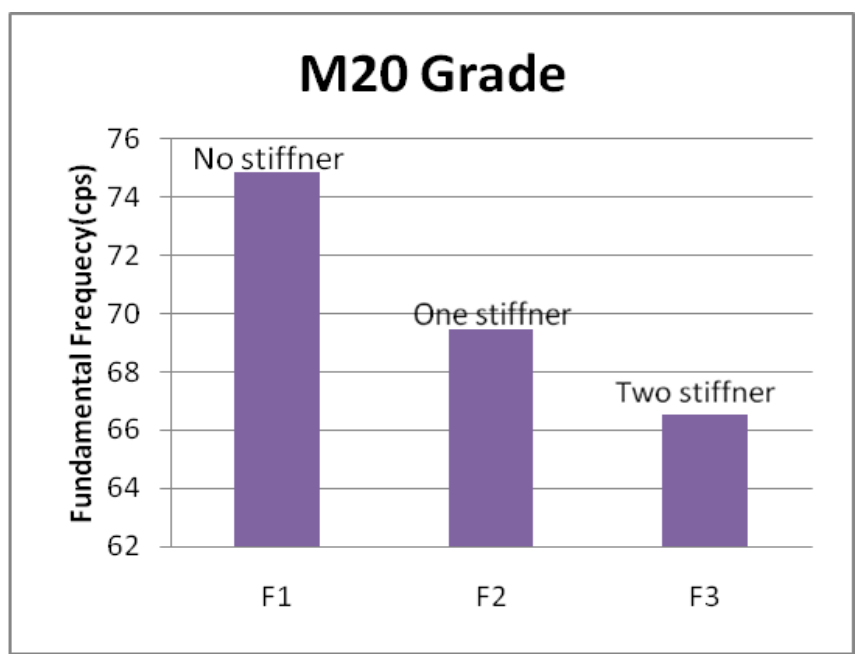

Chart-6:Fundamental Frequecy of M20 Grade 
Table -5: M25 Grade Fundamental Frequency

\begin{tabular}{|c|c|c|c|c|c|}
\hline \multirow{2}{*}{\multicolumn{2}{|c|}{ case }} & \multicolumn{4}{|c|}{ M25 grade } \\
\hline & & & $\omega(\mathrm{rps})$ & $\mathrm{f}(\mathrm{hz})$ & $\mathrm{T}(\mathrm{sec})$ \\
\hline \multirow{4}{*}{$\begin{array}{l}\text { Without } \\
\text { stiffner }\end{array}$} & $\lambda_{1}^{2}$ & $2.06 \mathrm{E}+05$ & 453.98 & 72.29 & 0.0138 \\
\hline & $\lambda_{2}^{2}$ & $2.01 \mathrm{E}+06$ & 1418.53 & 225.88 & 0.0044 \\
\hline & $\lambda_{3}^{2}$ & $5.03 \mathrm{E}+06$ & 2241.79 & 356.97 & 0.0028 \\
\hline & \multicolumn{3}{|c|}{ Fundamental frequency } & 72.29 & 0.0138 \\
\hline \multirow{4}{*}{$\begin{array}{l}\text { Stiffner } \\
@ \text { centre }\end{array}$} & $\lambda_{1}^{2}$ & $1.82 \mathrm{E}+05$ & 426.13 & 67.85 & 0.014 \\
\hline & $\lambda_{2}^{2}$ & $1.63 \mathrm{E}+06$ & 1274.94 & 203.01 & 0.0049 \\
\hline & $\lambda_{3}^{2}$ & $4.09 \mathrm{E}+06$ & 2021.26 & 321.85 & 0.0031 \\
\hline & \multicolumn{3}{|c|}{ Fundamental frequency } & 67.85 & 0.0147 \\
\hline \multirow{4}{*}{$\begin{array}{c}\text { Stiffner } @ \\
\mathbf{h} / \mathbf{3}\end{array}$} & $\lambda_{1}^{2}$ & $1.58 \mathrm{E}+05$ & 397.25 & 63.25 & 0.0158 \\
\hline & $\lambda_{2}^{2}$ & $1.88 \mathrm{E}+05$ & 434.16 & 69.13 & 0.0144 \\
\hline & $\lambda_{3}^{2}$ & $2.36 \mathrm{E}+05$ & 485.95 & 77.38 & 0.0129 \\
\hline & \multicolumn{3}{|c|}{ Fundamental frequency } & 63.25 & 0.0158 \\
\hline
\end{tabular}

Table -6: M30 Grade Fundamental Frequency

\begin{tabular}{|c|c|c|c|c|c|}
\hline \multirow{2}{*}{\multicolumn{2}{|c|}{ Case }} & \multicolumn{4}{|c|}{ M30 grade } \\
\hline & & & $\omega(\mathrm{rps})$ & $\mathrm{f}(\mathrm{hz})$ & $\mathrm{T}(\mathrm{sec})$ \\
\hline \multirow{4}{*}{$\begin{array}{l}\text { Without } \\
\text { stiffner }\end{array}$} & $\lambda_{1}^{2}$ & $1.97 \mathrm{E}+05$ & 443.47 & 70.61 & 0.014 \\
\hline & $\lambda_{2}^{2}$ & $2.02 \mathrm{E}+06$ & 1422.16 & 226.45 & 0.004 \\
\hline & $\lambda_{3}^{2}$ & $5.08 \mathrm{E}+06$ & 2252.91 & 358.74 & 0.002 \\
\hline & \multicolumn{3}{|c|}{ Fundamental frequency } & 70.61 & 0.014 \\
\hline \multirow{4}{*}{$\begin{array}{l}\text { Stiffner } \\
\text { (a)centre }\end{array}$} & $\lambda_{1}^{2}$ & $1.66 \mathrm{E}+05$ & 407.95 & 64.96 & 0.0153 \\
\hline & $\lambda_{2}^{2}$ & $1.64 E+06$ & 1279.89 & 203.8 & 0.004 \\
\hline & $\lambda_{3}^{2}$ & $4.11 \mathrm{E}+06$ & 2027.64 & 322.87 & 0.003 \\
\hline & \multicolumn{3}{|c|}{ Fundamental frequency } & 64.96 & 0.015 \\
\hline \multirow{4}{*}{$\begin{array}{c}\text { Stiffner@ } \\
\text { h/3 }\end{array}$} & $\lambda_{1}^{2}$ & $1.48 \mathrm{E}+05$ & 384.49 & 61.22 & 0.016 \\
\hline & $\lambda_{2}^{2}$ & $1.82 \mathrm{E}+05$ & 427 & 67.99 & 0.014 \\
\hline & $\lambda_{3}^{2}$ & $2.38 \mathrm{E}+05$ & 488 & 77.7 & 0.0128 \\
\hline & \multicolumn{3}{|c|}{ Fundamental frequency } & 61.22 & 0.016 \\
\hline
\end{tabular}

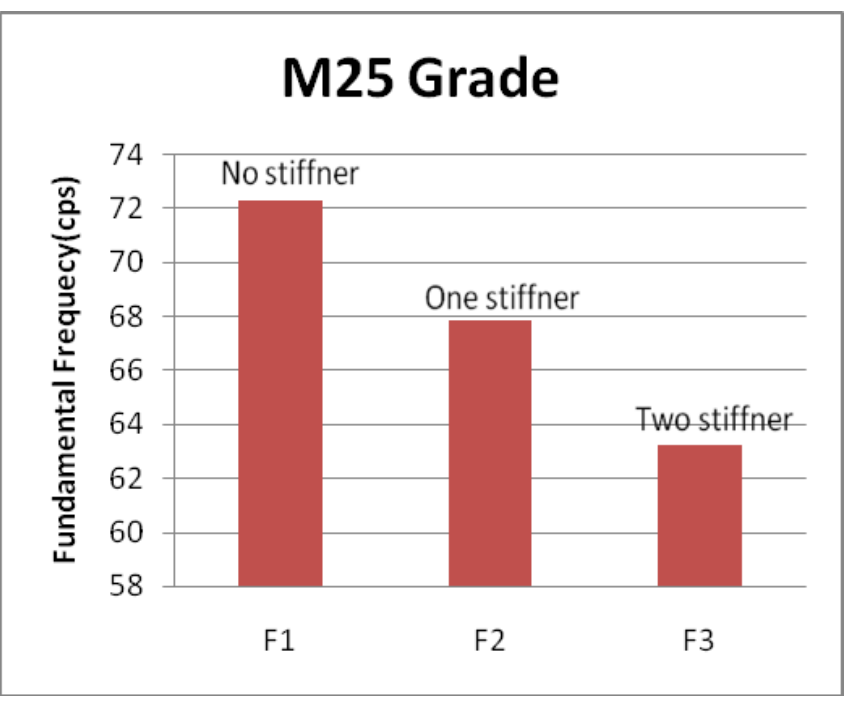

Chart-7:Fundamental Frequecy of M25 Grade

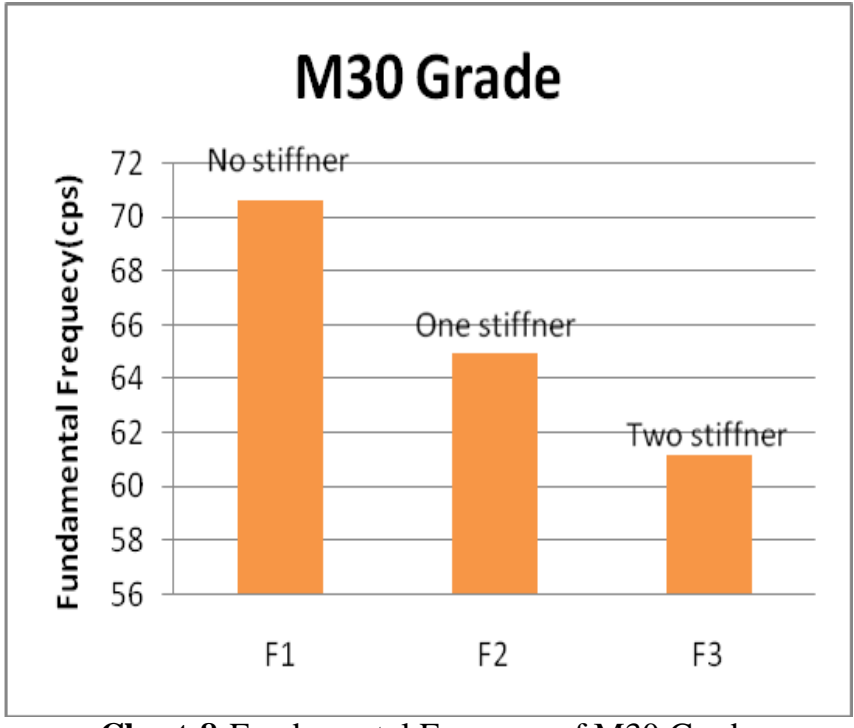

Chart-8:Fundamental Frequecy of M30 Grade

\subsection{Number of Stiffeners}

The strength of hollow and concrete filled column is enhanced by providing stiffeners. The capacity of column is enhance by increasing number of stiffeners as shown in graph 1 . This is due to stiffeners increases stiffness capacity and delay buckling action.

Stiffeners modeled in finite element software are as shown in figure6, 7, 8 and 9.

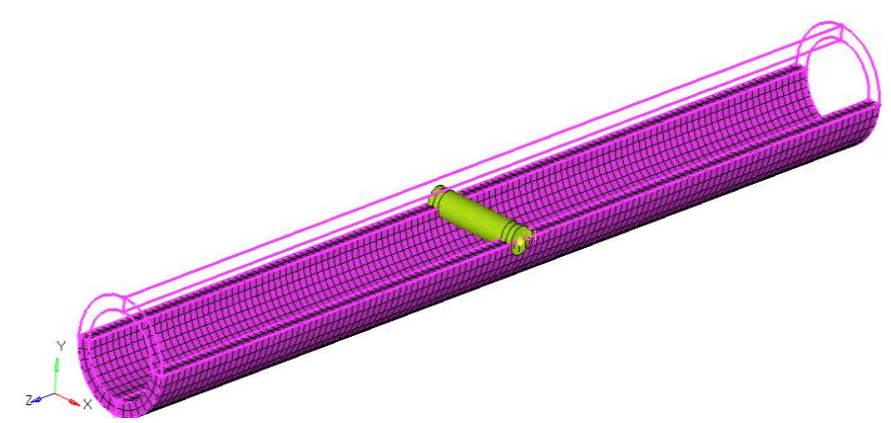

Fig-6 Hollow Tube with One stiffener

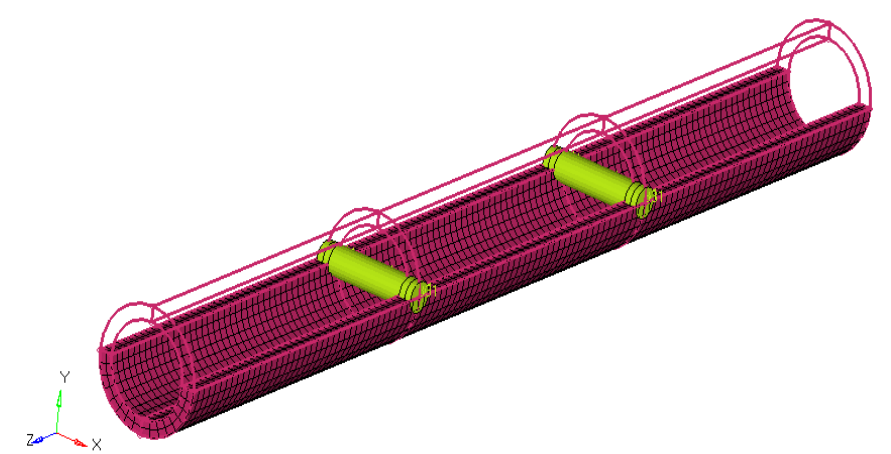

Fig-7 Hollow Tube with One stiffener 


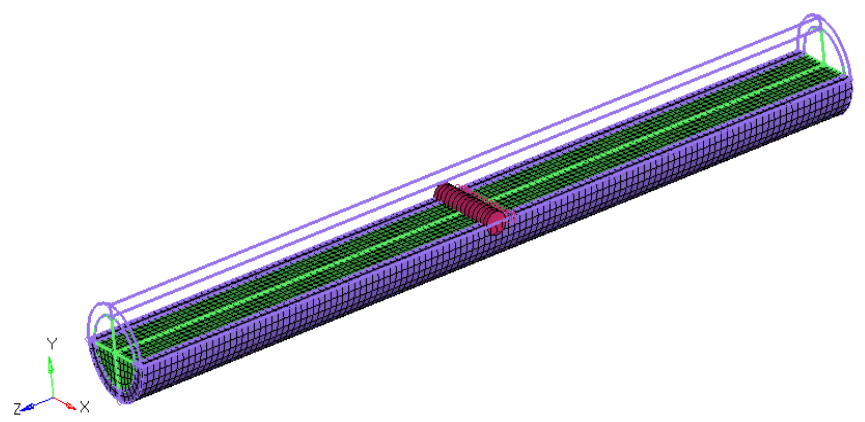

Fig-8 Hollow Tube with One stiffener

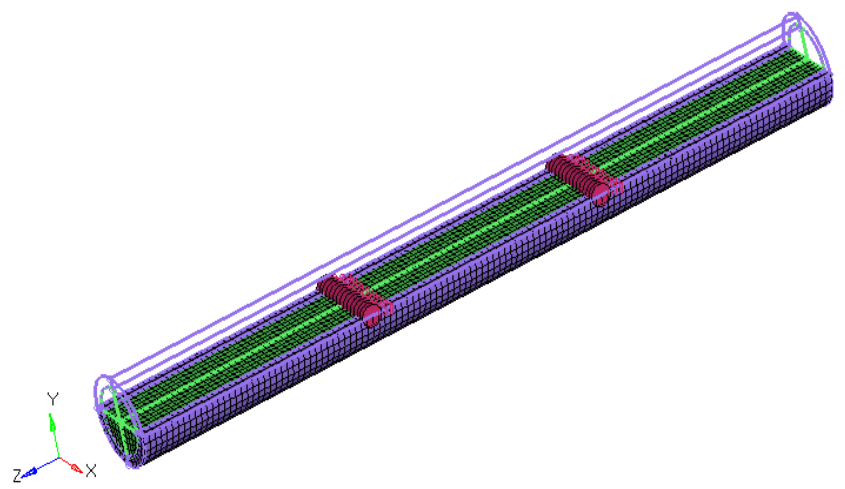

Fig-9 Hollow Tube with One stiffener

\section{CONCLUSIONS}

1. Increase in thickness of steel tube enhance the capacity $\left(\mathrm{P}_{\mathrm{u}}\right)$ of both Hollow and composite column due to confinement pressure increases with increase in thickness of steel tube.

2. As concrete strength is increase, the stiffness of column increases but column fails due to crushing of concrete which shows brittle failure behavior when filled with high grade of concrete.

3. Finite element model results are obtained from ABAQUS 6.10-1 and compare with Experimental results of hollow and composite column with different grade, thickness and number of stiffeners results in predicting the column behavior.

4. The strength of column with stiffeners is higher than without stiffeners.

5. As the number stiffeners increases, the Ultimate Capacity of both hollow and composite column is increased.

6. The vibration of Hollow column is greater than concrete filled column.

7. The Fundamental Frequency decreases with increase in number of stiffeners.

\section{REFERENCES}

[1]. American Concrete Institute (ACI), Building code requirements for structural concrete and commentary, ACI 318-95.

[2]. ABAQUS Documentation. Version 6.10-1

[3]. Eurocode 4. Design of composite steel and concrete structures. Part 1.1, General rules and rules for buildings (with UK national application document)
[4]. Ehab Ellobody, Ben Young, Dennis Lam (2006), "Behavior of Normal and High Strength Concrete-Filled Compact Steel Tube Circular Stub Columns", Journal of constructional steel Research 62 (2006) 706-715

[5]. Saenz LP. Discussion of "Equation for stress-strain curve of concrete" by P. Desayi, and S. Krishnan. Journal of the American concrete Institute 1964;61:1229-35.

[6]. Richart FE, Brandzaeg A, Brown RL. " A Study of the failure of concrete under combined compressive stresses". Bull. 185. Champaign (IL, USA): University of Illinois Engineering Experiment Station: 1928.

[7]. Mander JB, Priestley MJN, Park R. "Theoretical stressstrain model for confined concrete". Journal of structural Engineering, ASCE 1988; 114(8):1804-26.

[8]. LRDF. Load and resistance factor design specification for steel buildings. American Institute of steel Construction, 1999.

[9]. Hu HT, Schnobrich WC. "Constitutive modeling of concrete by using nonassociated plasticity". Journal of Material in Civil Engineering 1989:1(4):199-216.

[10]. Hu HT, Huang CS Wu MH, Wu YM. "Nonlinear analysis of axially loaded concrete-filled tube columns with confinement effect", Journal of structural Engineering, ASCE 2003;129(10):1322-9.

[11]. Giakoumelis G, Lam D. "Axial capacity of circular concrete-filled tube columns". Journal of Constructional Steel Research 2004;60(7):1049-68

\section{BIOGRAPHIES}

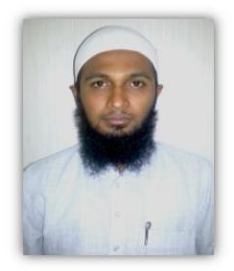

Athiq Ulla Khanr, Obtained B.E degree in Civil Engineering (First Class with distinction) during the year 2012 from Ghousia College of Engineering, Ramanagaram Affiliated to VTU Belgaum. Presently persuing Master of Technology in Structural Engineering at Ghousia College of Engineering, Ramanagaram. Also working on this topic for the dissertation under the guidance of Dr. N.S Kumar

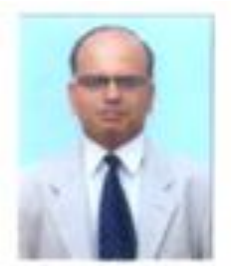

N.S.Kumar, Involved in the Research field related to behavior of Composite Steel Column since a decade. \& He has guided more than 15 M.tech projects including one M.Sc Engineering (by Research under VTU, Belgaum). Presently guiding four Ph.D Scholars under VTU Belgaum. Has more than 26 years of teaching \& 6 years of Research experience at Ghousia College of Engineering, Ramanagaram 